\title{
Cryoprotective ability of starch syrup in the composition of aromatic and fruit-berry ice cream
}

\author{
Galyna Polischuk, Oksana Bass, Tetiana Osmak, Natalia Breus
}

\author{
National University of food Technologies, Kyiv, Ukraine
}

\section{Keywords:}

Ice cream

Syrup

Composition

Freezing

Water

\section{Article history:}

Received 16.10.2018

Received in revised

form 11.12.2018

Accepted 31.05.2019

\section{Corresponding \\ author:}

Tetiana Osmak

E-mail:

osmaktg@ukr.net

DOI: $10.24263 / 2304-$

974X-2019-8-2-4

\section{Abstract}

Introduction. The purpose of the research is to study the influence of starch syrup of various carbohydrate composition and its compositional mixtures on the formation of physicochemical indicators of ice cream on the basis of sugar syrups.

Materials and methods. As a substitute of sugar for icecream was used starch syrup with different functional and technological properties - syrup caramel low-saccharification (SC) and glucose-fructose syrup (GFS) with a dry matter content of at least $78 \%$. The cryoscopic temperature was determined using Beckmann's thermometer, the content of frozen water was calculated in accordance with the obtained values of the cryoscopic temperature, the microstructure was investigated using a light microscope with a cooling chamber for increasing $x 400$ and $x 600$.

Results and discussion. For complete replacement of sugar in the ice cream the starch syrup of different degree of saccharinization was chosen: glucose-fructose syrup GFS (dextrose equivalent 98) and syrup caramel SC (dextrose equivalent 30). GFS, in comparison with control samples with sugar, due to the high content of mono-sugars, significantly reduces the cryoscopic temperature of the mixtures. While, the $\mathrm{SC}$ boosts this figure. Therefore, in order to maintain the recommended balance on the content of frozen water at each stage of low-temperature processing of ice cream mixtures, it is expedient to combine the cryoprotective capacity of the syrup with different dextrose equivalent. The ranges of optimal correlations between GFS and SC in compositions were calculated, allowing to receive the content of frozen water, according to control samples - from 30:70 to 40:60 for aromatic ice cream and from 50:50 to 90:10 - for fruit-berry ice-cream. Microstructural analysis of ice cream samples has demonstrated the expediency of complete replacement of sugar on the syrup compositions, which provides the formation of a more homogeneous finished product structure, compared with control samples with sugar.

Conclusions. The cryoscopic temperature of the mixtures, the content of the frozen water, and the size of the particles of the disperse ice cream systems can be adjusted by the use of starch syrup compositions with different dextrose equivalent. 


\section{— Food Technology —}

\section{Introduction}

Cryoscopic temperature $\left(t_{\mathrm{cr}}\right)$ of mixtures for production of ice-cream is one of the main physical characteristics that determine the nature of the process of cooling the water during freezing, hardening and storage of the finished product [1]. The resulting crystals of ice are unstable in time and can be detected due to disturbances in the temperature regimes of production and storage $[1,2]$.

Exactly the content of the chemical and physical-chemical bound water in the mixture for ice cream production affects on $t_{\text {cr }}$ that causes the crystallization process and the size of the crystals in the finished product [3]. Low molecularity, truly soluble in water compoundssucrose, lactose and salt reveal the best effect on the tcr of ice cream mixtures [4]. The role of proteins and polysaccharides in this process is mediated and manifested through the connection of water, which cannot be solvent, which leads to increase of concentration of solutions of simpleand double sugar, salts in the residual of free water [5, 6, 7].

The cryoscopic temperature of ice-cream mixtures, depends not only from the number of dissolved molecules, but also from their molecular weight. Substances of lower molecular weight exhibit greater cryoprotective capacity [8]. Therefore,simple sugars, compared with double sugars, have a greater influence on tcr of aqueous solutions [9].

Except for less cryoprotective ability of double sugars, they are able to intensively crystallize during storage with the formation of large crystal sizes ( $\leq 10$ microns) and their subsequent accretion $[10,11]$.

A special place in the market for frozen desserts is ice cream based on sugar syrups, which do not have milk components [12]. Within certain species of such ice cream there are certain requirements for the content of sweeteners, in particular, white crystalline sugar [13]. Thus, the content of sugar in aromatic ice-cream and fruit-berry is in the range of 20-22 to $30-32 \%$. It is sugar that traditionally performs the function of an intensive sweetener and a source of dry matter, the proportion of which is based on their total content in aromatic and fruit-flavored ice cream of about $80-90 \%$. Due to lower solubility, double sugars can form large crystals in ice-cream based on sugar syrups during its long-term storage. In order to prevent the appearance of a hard sugar chop on the surface of portions, sugar in this ice cream is recommended to replace on starch syrup, invert sugar or monosaccharin $[14,15,16]$ by $20-25 \%$. At the same time, starch syrup is the best alternate way thank to its price, safety indicators and functional-technological characteristics. Particular attention deserves polyfunctional technological properties of syrup of varying degrees of assessment, which are capable of amplifying, structuring ice cream and detecting cryoprotective ability [17, 18].

The authors for the first time have proved the expediency of a complete replacement of sugar in ice cream with milk base on syrup and its compositions. In the case of combination of high and low-sugar syrup, the degree of sweetness, the resistance to dampness, the aqueous phase, viscosity and the size of ice crystals and bubbles of the air are regulated [19, 20]. But especially important is the study of the process of freezing water in ice cream on the basis of sugar syrups - aromatic and fruit-berry. At the same time, information on the influence of starch syrup on the physico-chemical characteristics of ice cream in this group is absent.

The purpose of scientific research is to study the influence of starch syrup of various carbohydrate composition and its compositional mixtures on the formation of physicochemical indicators of ice cream on the basis of sugar syrups.

The research objectives are as follows:

- to study the cryoprotective ability of starch syrup with low and high dextrose equivalent and the possibility of combining the syrup in aromatic and fruit-berry ice cream with complete replacement of sugar; 
- to optimize the composition of carbohydrate complexes for the complete replacement of sugar in ice cream on the basis of the analysis of the patterns of freezing of water in mixtures for the production of ice cream;

- to find out the degree of influence of separate stages of low-temperature processing of mixtures with different carbohydrate composition on the content of frozen water;

- to confirm the efficiency of replacing sugar in the compositions of syrup by means of microstructural analysis.

\section{Materials and methods}

\section{Materials}

As a substitute of sugar for ice-cream was used starch syrup with different functional and technological properties - syrup caramel low-saccharification (SC) and glucose-fructose syrup (GFS) with a dry matter content of at least $78 \%$ (Table 1).

Table 1

Sensory attributes and physico-chemical properties of glucose syrup with different degree of starch conversion $[12,13]$.

\begin{tabular}{|l|c|c|}
\hline Indicator & Syrup Caramel (SC) & \multicolumn{1}{c|}{$\begin{array}{c}\text { Glucose-fructose syrup } \\
\text { (GFS) }\end{array}$} \\
\hline $\begin{array}{l}\text { Organoleptic } \\
\text { characteristics }\end{array}$ & $\begin{array}{l}\text { Homogeneous, very viscous, } \\
\text { colorless liquid. The taste is } \\
\text { moderately sweet, without } \\
\text { any foreign taste and smell. }\end{array}$ & $\begin{array}{l}\text { Homogeneous, liquid with } \\
\text { yellowish color. The taste is } \\
\text { over sweet, without any } \\
\text { foreign taste and smell }\end{array}$ \\
\hline $\begin{array}{l}\text { Dextrose equivalent } \\
\text { (DE) }\end{array}$ & 30 & 98 \\
\hline $\begin{array}{l}\text { Mass fraction of } \\
\text { glucose, } \%\end{array}$ & 10 & 2 \\
\hline $\begin{array}{l}\text { Mass fraction of } \\
\text { maltose, } \%\end{array}$ & 20 & 1 \\
\hline $\begin{array}{l}\text { Mass fraction of } \\
\text { maltotriosis, } \%\end{array}$ & absent & \\
\hline $\begin{array}{l}\text { Mass fraction of } \\
\text { higher sugars, } \%\end{array}$ & 70 & 42 \\
\hline $\begin{array}{l}\text { Mass fraction of } \\
\text { fructose, } \%\end{array}$ & absent & 98 \\
\hline Profile of sweetness & 30 & \\
\hline
\end{tabular}

The recipe composition of the experimental samples was developed in accordance with a typical mixtures composition of a wide assortment range [19]:

- aromatic ice cream (mass fraction of dry matter - 20,5-26,5\%, including sugar $20-26 \%$, citric acid $-0,2 \%$, stabilization system Kremodan ${ }^{\circledR} \mathrm{DC}-0,3 \%$ );

- fruit-berry ice cream (a mass fraction of dry substances - 25-35\%, including sugar 22$32 \%$, a mass fraction of dry matter of fruits and berries $-2.7 \%$, the content of stabilizing system Cremodan $\left.{ }^{\circledR} \mathrm{DC}-0.3 \%\right)$. 


\section{— Food Technology —}

For control 1 samples of ice cream with a minimum sugar content (aromatic $-20 \%$, fruit-berry $-22 \%$ ) were selected.

For control 2 - samples of ice cream with the maximum content of sugar (aromatic sugar $26 \%$, fruit and berry $-32 \%$ )

In the experimental samples, the mass fraction of dry matter of GFS and PCs and their composition mixtures (for the ratio between syrup from 10:90 to 90:10) is selected according to the most popular formulations within the permitted range of sugar contents, namely:

$-25 \%$ - for aromatic ice cream;

$-27 \%$ - for fruit-berry ice cream.

Contain a mass fraction of SS solids in the composition of GFS + PS in amounts of 100, $80,60,40,20$ and $0 \%$ respectively (samples 1-6).

Ice cream mixtures were pasteurized at $85 \pm 2{ }^{\circ} \mathrm{C}$ for $2-3$ minutes, cooled to $4 \pm 2{ }^{\circ} \mathrm{C}$ and maintained at this temperature for 2 hours [20].

Experimental ice-cream production was carried out on the frizer of the periodic action of the brand "Fibre-400", FPM-3,5 / 380-50. The investigated ice cream samples were hardened and stored in a freezer "Caravell" A / S at a temperature of minus $18-20^{\circ} \mathrm{C}[19$, 20].

\section{Methods}

The research was conducted in the following sequence:

- determined the cryoprotective capacity of caramel syrup and glucose-fructose syrup, as well as their compositions, by measuring the cryoscopic temperature of mixtures of aromatic and fruit-berries;

- studied the dynamics of freezing of free water during technologically significant stages of low-temperature processing of mixtures with different carbohydrate composition using two-factor regression analysis of experimental data;

- confirmed the expediency of using compositions of syrups by analyzing the microstructure and the external type of ice cream samples.

Cryoscopic temperature. The cryoscopic temperature of ice cream mixtures was determined using cryostat and Beckmann thermometer (TL-1) [15, 21].

The amount of frozen moisture. The amount of frozen moisture at different temperature regimes for non-dissociated molecular solutions was calculated according to the formula [15, 22]:

$$
\omega=\left[1-\left(t_{\mathrm{cr}} / \mathrm{t}\right)\right] \cdot 100
$$

where $\omega$ - number of frozen water, $\%$;

$\mathrm{t}$ - temperature, ${ }^{\circ} \mathrm{C}$.

Microstructural analysis. The microstructural analysis of the ice cream was carried out using a light microscope of the brand XS-2610 with a cooling chamber with an increase of $x 400$ and $x 600$. The sizes of air bubbles and ice crystals of ice cream samples were determined using a graduated eyepiece grid [15].

The results of the triple repetition study were processed by the method of mathematical and statistical processing at a given confidence probability $\mathrm{P} \geq 0.95$. 


\section{Results and discussion}

\section{Determination of the cryoprotective ability of syrups}

At the first stage of the work, the cryoscopic temperature of the samples of aromatic and fruit-berry ice cream of traditional composition with sugar and ice cream with complete replacement of sugar to syrup GFS and SC and their compositions (Figure 1).

According to Figure 1, the substitution of sugar to caramel syrup SC with a low dextrose equivalent does not allow to decrease the cryopreservation temperature to the significance of the traditional types of ice cream. Consequence of high values of $t_{c r}$ can become excessive freezing of free water with the creation of a coarse-crystalline structure. In the case of the use of only GFS, the reduction of $t_{c r}$ is very important that can only be taken for the production of soft ice cream and ice cream-soufflé. Therefore, it is obvious to combine high-sugar syrup with syrup of low DE at ratios, ranges of values that need to be clarified $[19,20]$.

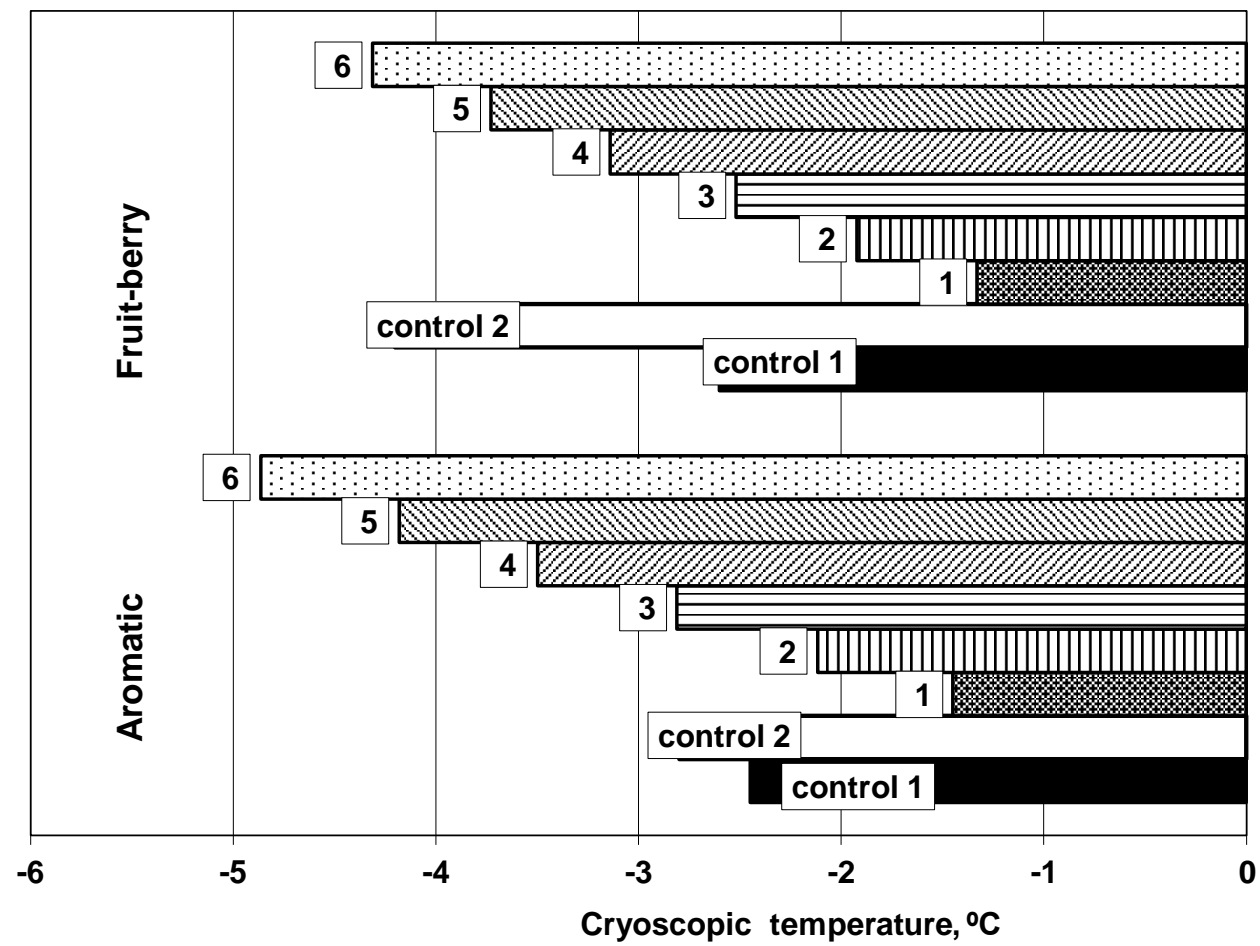

Figure 1. Cryoscopic temperature of ice cream samples with sugar and ice cream with complete replacement of sugar on GFS and PC Legend:

- control 1 - samples of ice cream with a minimum sugar content (aromatic $-20 \%$, fruit-berry $-22 \%$ );

- control 2 - samples of ice cream with the maximum content of sugar (aromatic - 26\%, fruit-berry - 32\%)

- samples 1-6: contain a mass fraction of SS solids in the composition of GFS + PS in amounts of 100, 80, 60, 40, 20 and $0 \%$ respectively 


\section{- Food Technology —}

\section{Study of free water freezing process}

For this purpose, based on the established values of cryoscopic temperatures (Figure 1), the content of frozen water in ice cream was calculated at technologically significant stages of low-temperature processing [22]:

- №1 - freezing (minus $6{ }^{\circ} \mathrm{C}$ );

- №2 - temporary storage of ice cream (minus $12{ }^{\circ} \mathrm{C}$ );

- №3 - storage of ice cream for a duration of up to 10 months (minus $18^{\circ} \mathrm{C}$ );

- №4 - storage of ice cream for a period of up to 12 months (minus $24^{\circ} \mathrm{C}$ );

- № 5 - hardening of ice cream in a continuous way (minus $30^{\circ} \mathrm{C}$ );

- №6 - hardening of ice cream in a continuous way (minus $40{ }^{\circ} \mathrm{C}$ ).

Figure 2 shows graphic 3D models that demonstrate the dynamics of water freezing at individual stages of the technological process, for the aromatic and fruit-berry ice cream obtained by the two-dimensional approximation method.

Two-dimensional approximation of the technological process made possible to study the process as a whole and at each stage separately by replacing the experimentally determined plane with an approximating one. The calculation error is $\varepsilon=0.05 \%$.

Figure 2 shows graphical 3D models that demonstrate the dynamics of water freezing at individual stages of the process for aromatic and fruit-berry ice cream.

On the plane XZ (Figure 2), are shown recommended ranges of dry matter content of low-sugar syrup in GFS + PC compositions, which satisfy the requirements for the content of frozen water for control samples of traditional composition with white crystalline sugar, are singled out. According to Figure 1, ranges of values of tcr for control samples of aromatic ice cream for a minimum (20\%) and a maximum (25\%) content of sugar are in the range from minus $2.45^{\circ} \mathrm{C}$ to minus $2.80{ }^{\circ} \mathrm{C}$. For control samples of fruit and berry ice cream for the minimum (22\%) and maximum (32\%) sugar content, the fluctuations of values are higher and range from minus 2.6 to minus $4.2^{\circ} \mathrm{C}$.

Taking into account this, the ranges of allowable values of frozen water in the studied samples of ice cream at the individual stages of the technological process are calculated. This made it possible to identify the rational content of low-sugar syrup PC in the GFS + PC complex for aromatic ice cream $(\mathrm{PC}=60-70 \%)$ and for fruit-berry ice cream $(\mathrm{PC}=10-50 \%)$ and to isolate these ranges of values in Figure 2

From Figure 2 shows the different character of freezing of water for aromatic and fruit-berry ice cream. Increased content of sugars in the fruit-berry ice cream makes it more effective to freeze water. At stage 1 (freezing) in aromatic ice cream during to recommended composition of the syrups, from 23 to $30 \%$ of water are frozen, and in fruit-berry - up to 25$43 \%$. Further hardening on 2nd stage increases the content of frozen water in these types of ice cream to $68-70 \%$ and $69-76 \%$, and at stages 5 and 6 - up to 91 and $93 \%$, respectively. Therefore, it should be noted that the most important role of the stages of freezing and tempering ice cream in the technological cycle of its production. Therefore, observance of the recommended low-temperature processing techniques in ice cream technology with high content of sugars is an extremely important condition for the guaranteed quality of the product. 


\section{- Food Technology —}

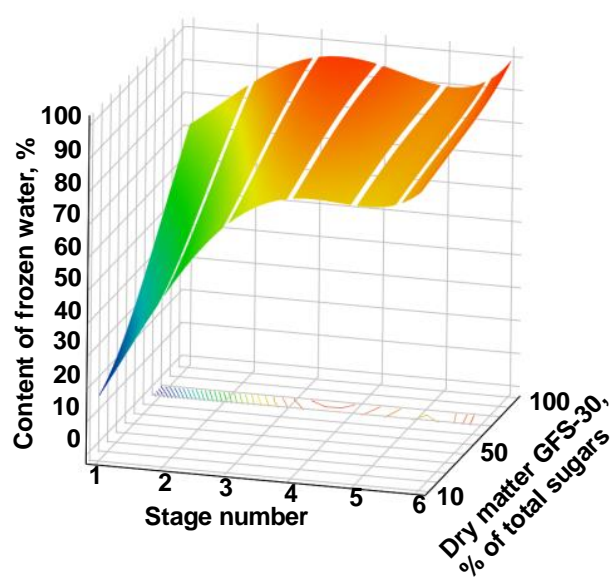

a

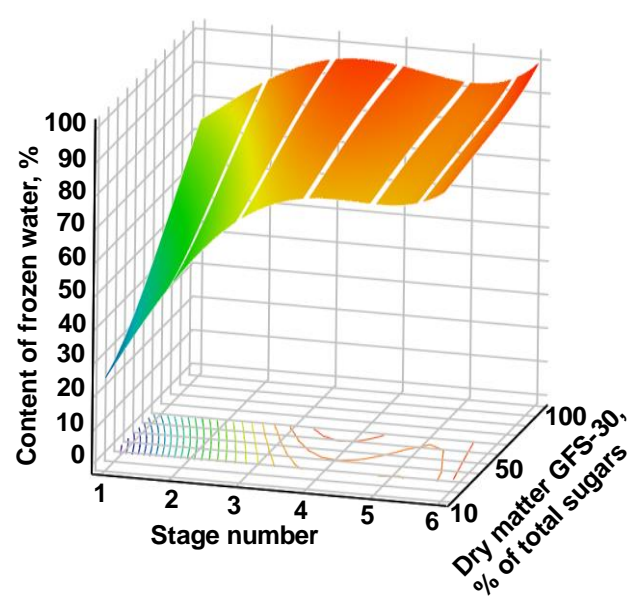

b

Figure 2. Graphic 3D models of water freezing dynamics at individual stages of the technological process for aromatic (a) and fruit-berry (b) ice cream

\section{Research of microstructural analysis of ice cream}

To further confirm the appropriateness of the complete replacement of sugar in ice cream, a comparative analysis of the microstructure of control samples with sugar and samples with complete replacement of sugars was carried out on compositions of syrups [20].

For ice cream, the aromatic ratio between the GFS and the PS was chosen within the optimal range of 40:60 (25\% by weight of sugars), and for fruit and berry ice cream - 60:40 (mass fraction of sugars - 27\%). Ice cream samples were subjected to low-temperature processing - hardening at a temperature of minus $30^{\circ} \mathrm{C}$ and storage at a temperature of minus $18^{\circ} \mathrm{C}$ for 1 month.

To illustrate the effect of higher structuring sugars and cryoprotectants-monosugars in the composition of the PS on the size of air bubbles and ice crystals, microphotographs of ice cream samples of classical and improved composition are presented (Figure 3). From the given microphotographs, it is evident that the syrup have a significant influence on the size of the disperse particles, especially in the case of a complete replacement of sugar in the aromatic ice cream composition of the GFS composition: PS $=40: 60$. The maximum size of air bubbles in ice cream dropped from 95 microns to 67 microns, and crystals of ice - from 60 microns to 39 microns.

A slightly less influence on the degree of dispersion of the air phase was observed for fruit-berry ice cream, the maximum size of air bubbles which decreased from 72 microns to 59 microns, and crystals of ice - from 45 microns to 40 microns. The higher content of dry matter, in particular, the presence of plant origin polysaccharides, contributed to a better distribution of air in ice cream and in addition to counteract the growth of ice crystals [2, 3 , $10]$. 


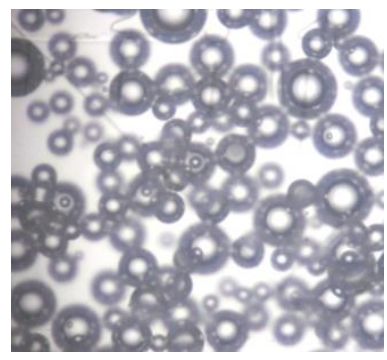

$a$

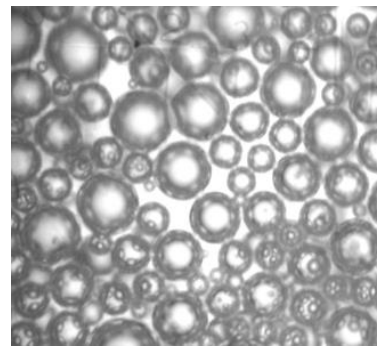

c

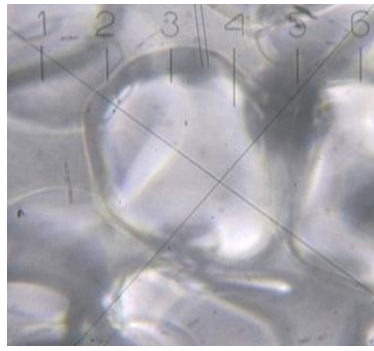

$\boldsymbol{e}$

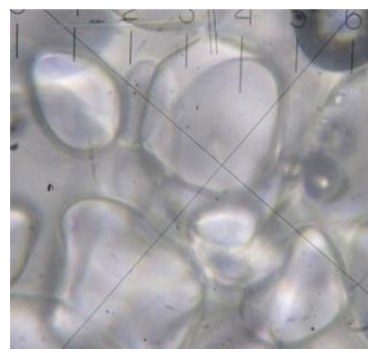

g

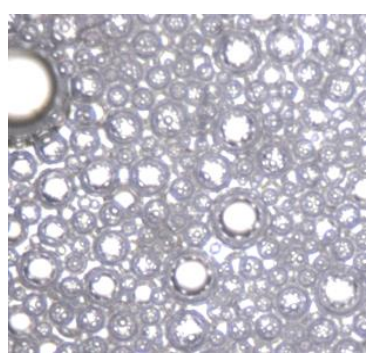

b

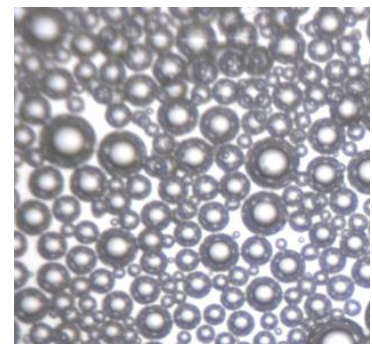

d

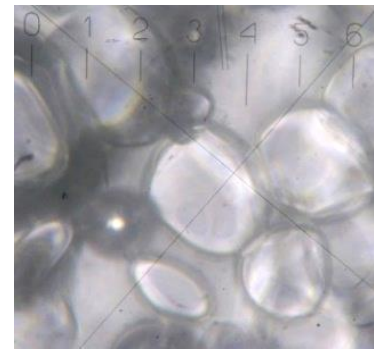

$f$

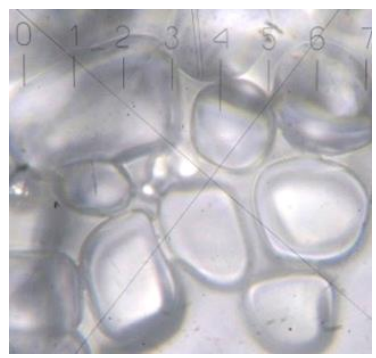

$h$

Figure 3. Air bubbles and ice crystals of aromatic ice cream with sugar (a, b) and syrup (g) and fruit-berry ice cream with sugar $(e, f)$ and $\operatorname{syrup}(g, h)$ 
In composition of such samples, the syrup with a high dextrose equivalence actively binds water and detects cryoprotective effect. Also low-sugar syrup structures water phase, stabilizing the air bubbles and mechanically counteract the excessive growth of water crystals. The obtained results correlate with the well-known scientifically proven recommendations regarding the expediency of a partial replacement of sugar to corn syrup $[10,11,23]$. At the same time, for the first time, the authors established the polyfunctional action of syrup in the formation of a wide range of physico-chemical characteristics, and scientifically achieved combinations of this sweetener with a different dextrose equivalent during to complete replacement of sugar in the composition of the finished product.

The prospect of further research is to carry out a research analysis of the technological role of starch in composition of ice cream on milk base and without milk components.

\section{Conclusions}

1. The cryoscopic temperature of mixtures for the production of ice cream can be adjusted by the use of starch syrup with different dextrose equivalent. Depending on the content of monosaccharides, the syrup exhibits a different cryoprotective capacity.

2. For complete replacement of sugar in the composition of ice cream on a composition of glucose-fructose syrup (dextrose equivalent 98) and caramel syrup (dextrose equivalent of 30) for ratios of 30:70 to 40:60 for aromatic ice cream and from 50:50 to 90: 10 for fruit-berry ice cream, in the ice cream at all stages of the technological process the nature of freezing of free water is similar to the samples of the classical chemical composition.

3. Composite mixtures of syrup have a comprehensive effect on the formation of disperse ice cream systems.

\section{Reference}

1. Adapa S., Schmidt K., Jeon I., Herald T., Flores R. (2000), Mechanisms of ice crystallization and recrystallization in ice cream: a review, Food Reviews International, 16(3), pp. 259-271.

2. Cook K. L. K., Hartel R. W. (2010), Mechanisms of ice crystallization in ice cream production, Comprehensive Reviews in Food Science \&Food Safety, 9, pp. 213-222.

3. Oguamah I.A., Oseh J.O., \& Yekeen P.N. (2014), Effects of freezing point depression on molecular weight determination of hydrocarbon mixtures. The Pacific Journal of Science and Technology, 15 (2), pp. 240-244.

4. Valera P., Pintor A., \& Fiszman S. (2014), How hydrocolloids affect the temporal perception of ice cream. Food Hydrocolloids, 36, pp. 220-228

5. Olenev Iu. A. (2002), Laktoza, sakharoza i mineralnye soli v smesiakh i morozhenom, Proizvodstvo i realizatsiia morozhenogo i bystro zamorozhennykh produktov, 5, pp.1517.

6. Leshchenko M. E. (2001), Osobennosti opredeleniia kholodilnoi nagruzki pri proizvodstve morozhenogo, Morozhenoe i zamorozhennye produkty, 1, pp. 22-23.

7. Cogne C., Laurent P., Andrieu J., Ferrand J. (2003), Experimental data and modeling of ice cream freezing, TransIChemE, 81, pp. 129-113.

8. Kaminska-Dworznicka A., Matusiak M., Samborska K., Witrowa-Rajchert D., Gondek E., Jakubczyk E., Antczak A. (2015), The influence of kappa carrageenan and its hydrolysates on the recrystallization process in sorbet. J. Food Eng., 167, pp. 162165. 
9. Herrera M.L., Cann J.I., Ferrero C., Hagiwara T., Zaritzky N.E., Hartel R.W. (2007), Thermal, mechanical, and molecular relaxation properties of stabilized frozen sucrose and fructose solutions, Food Biophysics, 2(1), pp. 20-28.

10. Arellano M., Benkhelifa H., Flick D., Alvarez G. (2012), Online ice crystal size measurements during sorbet freezing by means of the focused beam reflectance measurement (FBRM) technology. Influence of operating conditions, Journal of Food Engineering, 113(2), pp. 351-359.

11. Buyck J. R., Baer R. J., Choi J. (2011), Effect of storage temperature on quality of light and full-fat ice cream, Journal of Dairy Science, 94, pp. 2213-2219.

12. Pavliuk R.Yu., Poharska V.V., Berestova A.A. (2013), Innovatsiini tekhnolohii vitaminnoho plodovo-yahidnoho morozyva $\mathrm{Z}$ vykorystanniam zamorozhenykh dribnodyspersnykh dobavok z roslynnoi syrovyny, Vostochno-Evropeiskyi zhurnal peredovykh tekhnolohii, 10(64), pp. 57-62.

13. Goldfein K. R., \& Slavin J. L. (2015), Why Sugar Is Added to Food: Food Science. Comprehensive Reviews in Food Science and Safety, 14(5), pp. 644-656.

14. Buldo P., Kirkensgaard J.J.K., \& Wiking L. (2013). Crystallization mechanisms in cream during ripening and initial butter churning. Journal of Dairy Science, 96(11), pp. 6782-6791.

15. Marshall R. T., Goff H. D., Hartel R. W., (2013), Ice cream, Springer US, New York.

16. Ozdemir C. (2008), The effect of using alnernative sweetenersto sucrose on ice cream quality, Journal of Food Quality, 31(4), pp. 415-428

17. Parker K., Salas M., Nwosu V.C. (2010), High fructose corn syrup: Production, uses and publiche alth concerns, Biotechnology and Molecular Biology Reviews, 5(5), pp. 71-78.

18. Bogdanov E. (2009), Gliukoznye, maltoznye i gliukozno-fruktoznye siropy. Funktsionalnye osobennosti pri proizvodstve morozhenogo i zamorozhenyh desertov, Produkty \& Ingredienty, 3, pp. 76-78.

19. Bass O., Polischuk G., Goncharuk E. (2017), Investigation of viscous characteristics of mixtures of ice cream with starch syrup, Ukrainian Food Journal, 5, pp. 272-280.

20. Bass O., Polischuk G., \& Goncharuk E. (2018), Influence of sweeteners on rheological and qualitative indicators of ice cream, Ukrainian Food Journal, 7, pp. 41-53.

21. Olenev, Iu.A. (2002), Osnovnye strukturnye elementy i svoistva smesei i morozhenogo, Proizvodstvo i realizatsiia morozhenogo i bistro zamorozhennykh produktov, 4, pp. 8 10.

22. Maslikov M.M., Polischuk G.E. (2013), Unit for food's temperature control during their refrigeration, Ukrainian Journal of Food Science, 1(2), pp. 194-198.

23. Caniyilmaz E., Uçarkuş B., \& Karaman S. (2016), Optimization of formulation ingredients and aging time for ice cream processing using combined design approach. Journal of food processing and preservation, 40(6), pp. 1325-1338. 